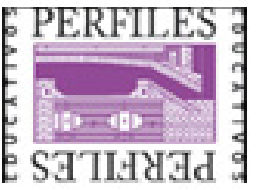

\title{
Perfiles Educativos
}

ISSN: 0185-2698

perfiles@unam.mx

Instituto de Investigaciones sobre la

Universidad y la Educación

México

Leyva, Juan

Walter Benjamin: critical constellations

Perfiles Educativos, vol. XXV, núm. 100, 2003, pp. 84-88

Instituto de Investigaciones sobre la Universidad y la Educación

Distrito Federal, México

Available in: http://www.redalyc.org/articulo.oa?id=13210007

How to cite

Complete issue

More information about this article

Journal's homepage in redalyc.org

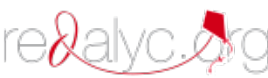

Scientific Information System Network of Scientific Journals from Latin America, the Caribbean, Spain and Portugal Non-profit academic project, developed under the open access initiative 
RESENAS

\title{
Walter Benjamin: critical constellations
}

\author{
GRAEME GILLOCH \\ Cambridge, Reino Unido, Polity, 2002, 304 pp. \\ POR JUAN LEYVA*
}

Teoría, crítica y sujeto

La transformación de los modelos de producción y los procesos ideológicos que la acompañaron en las últimas décadas del siglo $x x$ hicieron y continúan haciendo- una enorme presión sobre los modelos educativos y las disciplinas que los sustentan, lo que produjo, como centro crítico, una fuerte discusión sobre el sujeto y la subjetividad - punto de unión y división de individuo y sociedad-y las implicaciones epistemológicas que ello trae consigo. Las posiciones se extremaron, quizá, entre quienes declararon el carácter metafísico, autoritario y tendencioso —orientado por el capital-, de un sujeto individual, y quienes reafirmaron la existencia de ese sujeto y la posibilidad de contribuir a su construcción con un nuevo sistema de reglas y valores de rostro ya más ya menos conservador o liberal, pero con una flexibilidad apta

* Instituto de Investigaciones Bibliográficas-UnAm.

leyvac@servidor.unam.mx para las nuevas y múltiples formas de extensión del capital.

Entre la destrucción crítica, o desconstrucción, del individualismo y su entidad filosófica —el sujeto y la subjetividad-, y la reafirmación de una instancia rectora y unificadora del ser más allá de toda orientación de clase o grupo, el problema de las adscripciones disciplinarias -y por ende, curricularesse convirtió en uno de los más importantes, habida cuenta de que la división disciplinaria estaba (y está) dispuesta en términos de un individuo y una sociedad en discusión, dada su orientación clasista, racista, racionalista y, claro, machista. Los excesos de uno y otro bando son -a pesar de todo- sólo la máscara suave de la disputa por un nuevo lugar en la composición social, y no anulan, en ningún sentido, los logros críticos de este que bien podríamos llamar el más joven gran reajuste de la cultura a las necesidades del mercado.

La discusión sobre cómo afrontar ahora el estudio de diversos problemas -y cuál es la utilidad práctica de ello en términos de función social y rentabilidad - tiene que ver, pues, con una transformación en la concepción del sujeto y su relación con el mundo que hace indispensable la recuperación de sus formas de interacción y de elaboración de ésta -de autocomprensión y reformulación-, lo que no puede hacerse más que reconociendo su pluralidad, su papel de punto de confluencia. Ésta es, hoy por hoy, una de las zonas críticas de las humanidades.

Un pensador transdisciplinario

En esta perspectiva, un autor como Walter Benjamin, cuyo rasgo teórico más sobresaliente es haberse adelantado a la problemática actual en la imposibilidad de hablar de o de ceñirse a- una teoría de una sola disciplina, se vuelve, una vez más, de singular importancia. Ponernos al día ante la obra de este pensador es el foco del libro de Graeme Gilloch, tarea que cobra aun mayor reelevancia toda vez que el ejercicio interdisciplinario de Benjamin 
no se adscribe a ninguna etiqueta o corriente, 0 a ninguna cuestión coyuntural, sino que está llamado a la página por las continuas preguntas y callejones sin salida que la realidad le propuso en su posición de observador de la cultura, en busca de una explicación de largo alcance sobre la modernidad.

Como es sabido, la vida de Benjamin no fue fácil; sin embargo, su ambición y empresa -la de ser el mejor crítico literario de su generación-, que lo llevó, de hecho, a transformar el género y hacer evidente la inconsecuencia de adscribirlo al puro terreno de la literatura, da la impresión de haberse cumplido más allá de sus convicciones y el momento en que él mismo pudiera haber asistido a su reconocimiento, que se dio a pesar de todo: indiferencia de la academia, a la que no pudo ingresar porque los revisores de su única oposición no entendieron gran cosa (hoy la crítica valora El origen del drama trágico alemán, el ensayo por el que fue invitado a no volver a presentarse ante el jurado, como su obra maestra); oposición e intento de dominar su pensamiento por parte de algunos de sus amigos (Adorno, Scholem, Horkheimer, a veces Brecht); discontinuidad en sus tareas periodísticas; calamidades económicas; persecución antijudía; crisis depresivas...

Por otro lado, la difícil situación de Alemania durante casi toda la primera mitad del siglo $x x$ y la muy poste- rior edición de los escritos de Benjamin con respecto a su formulación original aunque algunos de los más importantes se conocían desde los cincuentas y principios de los sesentas-, fueron, sin duda, factores de peso en la retardada y problemática recepción de su pensamiento, a partir, sobre todo, del fin de la década hippie.

La fecundidad de su obra -ese reconocimiento final y continuado- surge, en mi opinión, de sus más grandes cualidades como ensayista: la larga, lenta, ponderada meditación; la atención aguda y precisa a los fenómenos de su tiempo, la enorme calidad de su trabajo como lector. Su pluma se mueve en una gran diversidad temática, y en diálogo y polémica con algunos de los grandes pensadores de su época y las herencias más pertinentes a su hacer: Kant, Hegel, quizá Husserl y los neokantianos, Freud, Marx, Luckács, Simmel, la tradición hebrea, Proust, Valery, el surrealismo...

\section{Historia y modernidad}

De ahí que, a fin de alcanzar la comprensión global de una obra más bien dispersa, Gilloch trabaje sobre dos ideas fundamentales para el pensador alemán donde la diversidad halla su núcleo: la noción de vida del objeto posterior al momento de su producción o emisión original; y la de su reconstrucción y recuperación, que, de igual modo que lo desnuda y exhibe como expresión de una época, lo constituye en revelador del devenir $y$, por encima de todo, de una actualidad sólo visible en perspectiva con la herencia que dicho objeto hace palpable. Puede tratarse de un juguete, una postal, un edificio o una calle, o bien de un mueble, una obra literaria, una película... Las elecciones temático- metodológicas de Benjamin se cifran, como he dicho, en su preocupación por entender la modernidad, preocupación que para el Jauss de fines de la década de la psicodelia es un tanto incomprensiva de Baudelaire (el creador de la noción vigente de modernidad) y el cruce hecho por éste entre lo clásico y lo actual, lo eterno y la moda, lo contingente, lo verdaderamente trasmisor de vida (Jauss, 1976, pp. 7181). En realidad, más que de incomprensión se trató de ambigüedad, o indeterminación, y polémica. Benjamin decidió hacer de la modernidad el principal foco de la crítica, en vista de que este proceso nos cerca, nos rodea y orienta la vida en su conjunto, pero no estuvo dispuesto a aceptarla del todo, ni de la misma manera que el poeta parisino (el propio Baudelaire fue muy contradictorio frente a su época).

Gilloch explica así, a lo largo de siete capítulos, las grandes temáticas del autor berlinés: la fragmentación cultural; el consumismo y la mercantilización del mundo; la ciudad y la vida urbana 
como experiencia central y definitoria del ser moderno; el predominio de los medios de comunicación y la masificación del arte; los cambios tecnológicos y la noción de progreso, y, finalmente, el profundo desarraigo y alienación de los intelectuales modernos. Todos estos temas encuentran en el capítulo final - "Love at last sight"-, sobre la lectura benjaminiana del poema de Baudelaire, "A une passante", una síntesis excepcional y una propositiva interpretación de lo que para Benjamin significó la modernidad. Tal universo temático convierte al autor de las Iluminaciones, de acuerdo con Gilloch, en una superestrella de la academia actual, debido, sobre todo, a

las múltiples y complejas formas en que sus ideas, temas y observaciones son crecientemente reconocidos como de especial significación y como una suerte de resonancia del actual análisis sociocultural de corte postmoderno. El consumo voraz y la extendida mercantilización; la agitación de la experiencia urbana; la proliferación de nuevas tecnologías comunicacionales y la sobresaturación de imágenes; las consecuencias opresivas y de destrucción atribuibles al 'progreso' y al conocimiento científico; la preservación de las valiosísimas contra-historias de grupos oprimidos, y el alto valor de la memoria colectiva o el testimonio individual, todas esas preocupaciones, no han disminuido enimportancia sino que la poseen incluso en un grado mucho mayor que cuando Benjamin escribía (pp. 1112, trad. JL).

Benjamin quería transformar la crítica, pero también las relaciones sociales, mediante un difícil compromiso entre el marxismo y teorías menos políticamente orientadas que no fácilmente concordaban (ésa fue una de sus grandes apuestas). Sabía, sin embargo, que el del arte era su terreno principal, y, desde ahí, en ningún momento dejó de dedicarse a leer y observar con atención el mundo y el pensamiento que lo rodeaba; a reflexionar con él y en torno a él, sin ceñirse a consignas programáticas a la hora de estar frente a la página propia o ajena. Por ejemplo, en la número 11 de las tesis sobre filosofía de la historia —no destinadas a publicación - anota que el progreso no es propiamente un beneficio para los trabajadores, sino el refinamiento de los medios para su explotación, en una idea que polemiza con la ética protestante $y-$ como observa Gilloch, p. 226 - también con el marxismo ortodoxo ("vulgar", diría Benjamin en la traducción de Aguirre, 1973, p. 185).
Su obra -a menudo inconclusa, desesperante a veces en su morosa dificultad- constituye una prolongada interrogación acerca de las grandes transformaciones habidas en los siglos XIX $y$ el de las mayores guerras; y es una lástima que su decisión de desaparecer en 1940 por vía de la morfina, en una cárcel de los Pirineos, nos haya impedido asistir a la lectura de un ensayo sobre, por ejemplo, los Beatles, o el cómic contracultural; o bien -más recientemente y con buena fortuna longeva - la renovación del kitsch, el tragicista mundo del dark, el table dance y la globalización, las universidades patito o el cúmulo increíble de teratológicos bares juveniles. Esos ensayos, sin embargo, están prefigurados en su hermenéutica, y quien haya querido o quiera escribir sobre tales temas encontrará en Benjamin, no un teórico sistemático, pródigo en definiciones acabadas, exento de contradicciones, 0 un pergeñador de párrafos abúlicos e insustanciales, pero sí un basamento crítico de difícil sustitución; en palabras de Gilloch (p. 237), no hallará trabajos terminados, sino, ante todo, los trucos y las herramientas del oficio.

Con el libro de Gilloch, estamos ante una empresa cuyo rasgo más sobresaliente es la claridad con que brinda los corolarios de algunas de las más difíciles cuestiones o puntos oscuros que han surgido de la lectura del ensayista alemán, engarza- 
dos en el proceso doble de la reflexión y las preocupaciones íntimas, y los momentos histórico-culturales en que Benjamin escribía. Sin que sea su propósito la profundidad conceptual de una obra colectiva como Walter Benjamin: Theoretical questions (Ferris, 1996), Critical constellations no elude, sin embargo, las dificultades y, al juntar las piezas para la comprensión, se convierte en un complemento de Theoretical... en la tarea de aclarar - hasta donde es posible- cuestiones tan arcanas como el concepto de experiencia o las relaciones que Benjamin tejió entre ese concepto y la reelaboración de la experiencia en el pensamiento y su enunciación (sorprende, eso sí, la omisión en este análisis del trabajo de Benjamin sobre Hölderlin).

Este libro viene a ser, en suma, un utilísimo manual para leer la obra de ese hombre que - ante la perspectiva de ser devuelto a un campo de concentración en la Francia ocupada- decidiera quitarse la vida en un acto que, de modo paradójico y terrible, parece haber causado un efecto tal sobre la guardia española que al día siguiente permitió al grupo de perseguidos - entre los que se contaba Arthur Koestler, uno de los primeros en narrar el suicidio de Benjamincontinuar su tránsito hacia Lisboa, para, finalmente, proseguir sus vidas en otros lugares, lejos de la guerra.
Crítica y memorias

Como no olvida Gilloch, la reconstrucción del pasado, para Benjamin, implica su recuperación fragmentaria mediada por el lenguaje; ello compromete a la autobiografía o al texto literario y sus métodos, pero también, por ejemplo, a la historiografía, a la que asigna la tarea de recuperar, con prioridad, la memoria de aquellos que han sido olvidados por el historiador convencional (he aquí su mesianismo de raíz teológica). Benjamin supone, o presupone, la inaptitud o extremada limitación que el lenguaje posee como instrumento de la memoria, y así, no deja de insistir en que, más que el pasado, existe apenas la recuperación de su escenario mediante una labor similar a la de un hombre que cava, con todo y el riesgo de no terminar sino revolviendo una y otra vez el terreno, sacando ciertas imágenes pero ocultando otras (Benjamin, 1996, p. 10), imágenes, "constelaciones" que, finalmente, entregarán su valor de pasado recuperado sólo en el instante en que lleguen a cruzarse con un presente capaz de iluminarlas, de otorgarles un puntual, pero, inevitablemente, provisorio sentido.

La visión de la cultura de Benjamin está permeada por esta irrenunciable noción de su fragilidad, falta de eternidad y renovada y crítica pertinencia; pero, también, por la no menos irrenunciable necesidad de su recupera- ción, del continuo ejercicio de la memoria y la pausa, sin las cuales -y éste sería para él uno de los peligros de la modernidad - no hacemos más que malbaratar nuestra humanidad a cambio de la pequeña moneda de lo actual, infinitamente menor, en su valía, a nuestra herencia (Benjamin, 1973, p. 173). "En toda época -escribió en el año de su muerte y con leve resonancia brechtiana, ha de intentarse arrancar la tradición al respectivo conformismo que está a punto de subyugarla. [...] El don de encender en lo pasado la chispa de la esperanza sólo es inherente al historiador que está penetrado de lo siguiente: tampoco los muertos estarán seguros ante el enemigo cuando éste venza" (ibid., pp. 180-181).

La herencia de Benjamin nos obliga a, y nos permite, por ejemplo, reflexionar, ahora, sobre el papel de la enorme concentración del capital y control del mercado que ejercen empresas como McDonald's, Nike, Nestlé, Samsung o Bayer, ofreciendo una imagen de alta eficiencia que en opinión de muchos el resto del mundo debería copiar, pero ocultando el hecho de basar una parte de su plusvalía en la discriminación racial, el colapso ecológico, la hiperexplotación y el esclavismo infantil, no ya en la aséptica y glamorosa Europa o los Estados Unidos, sino en Asia y África (Werner y Weiss, 2003); o ese capitalismo intermediario que a la som- 
bra de las maquiladoras y ciudades de vínculo social frágil destruye generaciones de jóvenes en un subterráneo y globalizado comercio sexual, en Ciudad Juárez, Guatemala o algunas zonas de Argentina. A tono con los requerimientos académicos actuales, la pregunta y la discusión continua y amplia $-\mathrm{y}$ sus resultados - sobre qué visión de la cultura y del ser humano puede fundamentar tales acciones, y cómo contrarrestarlas, bien podrían adscribirse, como otros, a la lista de los índices universitarios de eficiencia. Por último, el libro de Gilloch nos recuerda la necesidad de una traducción anotada de los escritos de Benjamin hecha a la luz de nuestro momento $y$ los logros acumulados por la crítica y la filología en las últimas décadas. Las traducciones más importantes de su obra a la lengua española datan nada menos que de entre 1970 y 1973.

\section{REFERENCIAS}

BENJAMín, W. (1996), Escritos autobiográficos, versión española de Graciela Calderón y Griselda Mársico, Madrid, Alianza. - (1973), Discursos interrumpidos I, trad. de J. Aguirre, Madrid, Taurus.

FERRIS, D. (ed.)(1996), Walter Benjamin: Theoretical questions, Stanford, Stanford University Press.

JAUSS, H.R. (1976), La literatura como provocación, trad. de J. Gordo, Barcelona, Península.

WERNER, Klaus y Hans Weiss (2003), El lado oscuro de las marcas, México, Sudamericana. 